\title{
Fresh views on the early history of Indo-European and its relation to Uralic
}

Kloekhorst, Alwin \& Pronk, Tijmen (eds.). 2019. The precursors of Proto-Indo-European: The Indo-Anatolian and IndoUralic hypotheses (Leiden Studies in Indo-European 21). Leiden \& Boston: Brill. viii +235 pp.

\section{Introduction}

The volume at hand presents a series of articles on two hypotheses relevant for Indo-European linguistics: the much-discussed socalled Indo-Anatolian hypothesis (previously also known as "IndoHittite hypothesis"), which implies that the Anatolian branch of IndoEuropean consisting of Hittite, Luvian and other closely related languages was the first to branch off from Proto-Indo-European; and the Indo-Uralic hypothesis, which claims that the Uralic language family is related to the Indo-European family. Many of the articles discuss both hypotheses, albeit to varying extents, and there are a few articles that deal exclusively with the Indo-Anatolian hypothesis.

It is good to remark here that the Indo-Uralic hypothesis is in general much more widely accepted among Indo-Europeanists (see, for example, Beekes 2011: 31-33; Rasmussen 2005) than on the Uralic side, and that most of the scholars who have worked on the topic in recent years are Indo-Europeanists. This is also reflected in the authors of the book, who are mostly IndoEuropeanists and a few Uralicists also known for their work with Indo-European (Petri Kallio and Mikhail Zhivlov), although it must be noted that many contributing Indo-Europeanists have also worked with contacts or relations between Indo-European and Uralic at some point.

One of the editors, Alwin Kloekhorst, is one of the bestknown scholars of the Anatolian languages and the author of the Etymological dictionary of Hittite (Kloekhorst 2008a). Kloekhorst has discussed aspects of the Indo-Anatolian hypothesis in several publications (such as Kloekhorst 2016, 2018) and has also done work on the Indo-Uralic hypothesis from an Anatolianist point of view (Kloekhorst 2008b).

\section{Notes on the articles}

The book opens with a short preface, followed by a detailed and 
lengthy introduction ("Introduction: Reconstructing Proto-IndoAnatolian and Proto-Indo-Uralic") by Kloekhorst and Tijmen Pronk familiarising the reader with the problems dealt with in the articles. The reader gets a good impression of the present situation of research on these aspects of Indo-European linguistics. The editors argue that since PIE did not "come out of nowhere", it is worthwhile to look for relatives to it. They have an optimistic view on Indo-Uralic, but possible further connections in the framework of the Nostratic hypothesis are mentioned only briefly. Kloekhorst and Pronk underline the need to first proceed with the internal reconstruction of Proto-Indo-European before external cognates can be found, and they stress the need to be aware of protophonetics, especially when it comes to the Indo-European "laryngeal" phonemes. Regardless of whether one is sceptical or optimistic about long-range comparison, these remarks made by the editors can be considered useful for anyone working with comparisons that involve several language families and reconstructed proto-languages.

The presentation of the IndoAnatolian hypothesis is very informative, and one gets a good overall picture of it. The editors list the innovations (morphological, pho- nological, syntactic, and semantic innovations that concern both lexicon and morphology) that have occurred either in Proto-Anatolian or in the common predecessor of the other Indo-European languages. In total, 23 such innovations are listed, with semantic (8) and morphological (10) innovations being much more numerous than phonological (3) or syntactic (2). (It is good to mention here that Serangeli [2019: 7, footnote 3] criticises Kloekhorst and Pronk's listing of innovations and argues that the number of morphological innovations can be reduced: she notes that in the list of non-Anatolian Indo-European innovations, the thematisation of nouns could be treated as one innovation, but Kloekhorst and Pronk list all of the thematised nouns separately, which makes the number of innovations appear higher than it actually is.)

The editors also discuss the research history of the hypotheses, noting that for most of the 2oth century the Indo-Anatolian hypothesis was neglected, but that in the recent decades it has become widely accepted in Indo-European studies. However, references to more sceptical opinions (such as Rieken 2009 and Adiego 2016) on the topic are also provided.

It should be noted here that the terminological questions related 
to the Indo-Anatolian hypothesis are only briefly discussed, and in the articles that follow, the various stages of reconstruction (ProtoIndo-Anatolian, Proto-Indo-European in its classical sense and more shallow stages of reconstruction) are referred to using various names, which might be a bit puzzling to a reader who is not familiar with Indo-European linguistics. It would have been good to provide more discussion of the terminological questions, as the names of the various taxonomical entities can be somewhat confusing at times. A recent article by Thomas Olander (2019) deals with the terminology concerning Indo-Anatolian and other stages and nodes of Indo-European, and it can be warmly recommended as an accompanying piece of reading.

The introduction is followed by the article "The Proto-Indo-European suffix *-r revisited" by Steffan Heinrich Bauhaus, which discusses the history of the IE locative suffix ${ }^{*}-r$. The article offers interesting explanations of this suffix, which can be reconstructed to the IndoEuropean proto-language based on relictal forms in the IE languages. Bauhaus argues that ${ }^{*}-r$ was originally a locative suffix, which was later reanalysed as an adverbial ending. It can be reconstructed to adverbs such as ${ }^{\star} k^{w}$ or (> Latin $c \bar{u} r$ 'why', Sanskrit kár-hi 'when'), and traces of this ${ }^{*} r$ also appear in nominal formations, such as Greek

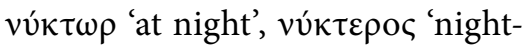
ly' and Latin nocturnus 'nightly'.

Indo-Uralic aspects are also dealt with briefly at the end of the paper. The author mentions Komi kor 'when' and the Hungarian "dative" (usually called sublative in the Hungarian grammar) in -ral-re as possible Uralic cognates of the IE locative. However, this is not very convincing, as the Hungarian case ending is probably originally a grammaticalised noun (MSzFE: 523; UEW: 883 , s.v. ${ }^{*}$ ray3; Sárosi 2003: 171) and, in any case, it does not represent a continuation of any Proto-Uralic case ending, so it is very unlikely that the $-r$ - element here has anything to do with the Indo-European locative ${ }^{*}-r$. The background of the element $-r$ in Komi kor 'when' remains unknown to me (KESKJ gives no explanation for this element), but deriving the ${ }^{*} r$ in this isolated form from an Indo-Uralic locative suffix would certainly require more evidence.

The spatial relations in Uralic that the author refers to (the three series of local cases) are typical of only certain Uralic languages (such as Finnic, Permic or Hungarian) and not of the family as a whole, to say nothing of Proto-Uralic, which most certainly had a much 
simpler spatial case system (Janhunen 1982: 30-31).

In the article "Pronouns and particles: Indo-Uralic heritage and convergence", Rasmus Bjørn offers an interesting review of the old problem of Indo-Uralic pronouns, which are often considered among the most promising pieces of evidence for the Indo-Uralic hypothesis. His article is a welcome and detailed account of the problems involved in the comparison of personal and demonstrative pronouns, but it does not solve the old problems connected to the vowel correspondences between the Indo-European and Uralic pronouns. It is notable that the reconstruction of the vocalism of the personal pronouns is uncertain even within Uralic; see Janhunen (1981: 232-233). For an attempted solution to this problem, see Honti (2012), who is not mentioned by Bjørn. One has to ask: if the vocalism of the PU pronouns cannot be properly reconstructed, how useful is it to compare them with their alleged IE cognates? Here, it would be wise to heed the words of the editors in the preface about the need to work out inner-IE or inner- $U$ reconstructions before attempting a comparison between the two families.

There are also various smaller points of criticism that I would like to point out:
Surprisingly, the "wider affinities with Yukaghir" are mentioned in the article (p. 3). Comparisons with Yukaghir have frequently occurred in earlier works on IndoUralic (such as Hyllested 2009), but Aikio (2014: 41-43) has shown that these affinities can more probably be explained as loan relations than genetic affinities, and references to the genetic relationship of Yukaghir and Uralic could be left out of these speculations for now.

The part about the Proto-Uralic interrogative particle (reconstructed as ${ }^{\star} k u$ by the author) also requires some remarks. When listing the functions of this particle in Finnic, or Balto-Fennic in the author's terminology, the author mentions "Saami -gŏ" (without specifying which Saami language is meant here) among the Finnic forms (p. 34). This gives a misleading picture of the taxonomy of Saami within Uralic.

Moreover, the idea (mentioned only hesitantly by the author) that the Kamassian particle - go could be borrowed from Tocharian (p. 37) seems very unlikely to me, as it is hard to fit it into the chronology of Samoyed and Tocharian linguistic history. The general uncertainness of Tocharian-Samoyed contacts in the light of modern research should be kept in mind (Kallio 2004) although these contacts remain a 
possibility, very little has actually been proved. One would also expect quite an intensive contact if an enclitic particle is borrowed, and it would be surprising to find this particle only in Kamassian.

In footnote 10 (p. 42), Bjørn refers to the "Uralic partitive *- $t V$ ", which possibly corresponds to Indo-European - $d$ in inanimate pronouns such as ${ }^{\star}$ tod 'this, that'. However, the case in question is the Proto-Uralic ablative (or, at least, this is the function generally reconstructed for that case), the partitive function having developed in Proto-Finnic or at an earlier Finno-Saami-Mordvin stage at best (this case ending is discussed further in Mikhail Zhivlov's article in the volume, p. 223).

The reconstruction of $\mathrm{PU}{ }^{*} t,{ }^{*} s$ in footnote 11 gives a misleading picture of Proto-Uralic phonology (p. 43). The table implies that PU `'s, which yielded Samoyed ${ }^{*} s$, should rather be reconstructed as ${ }^{*} s$, which would have then been retained in Samoyed, whereas ${ }^{*} s$ (which yielded ${ }^{*} t$ in Samoyed) would have been an affricate ${ }^{\star} t s$. Whereas the reconstruction of ${ }^{*} s$ as ${ }^{\star} t s$ would make the change ${ }^{*} s>{ }^{*} t$ in Samoyed less odd typologically, there are various counter-arguments to that, one being the loanword evidence ${ }^{*}{ }^{*} s$ is usually the substitute of ${ }^{*} c$ in IndoIranian loanwords, whereas plain ${ }^{*} s$ is the substitute of Indo-Iranian and Indo-European ${ }^{\star} s$; Holopainen 2019: 51, 334-336). Also, the complicated developments of $\mathrm{PU}{ }^{*} s$ to ${ }^{\star} k$ in Mator (Kümmel 2007: 98; Zhivlov 2018) are better explained if we reconstruct this phoneme as $\mathrm{PU}{ }^{\star} \dot{s}$ (or ${ }^{\star}$ ć) and not ${ }^{\star}$ s.

Dag Haug and Andrei Sideltsev discuss the problems of IndoAnatolian syntactic reconstruction in their article "Indo-Anatolian syntax?", concluding that the Anatolian "bare interrogatives" such as Hittite kuiš 'who' and kuit 'what' cannot be derived from the same system as the corresponding pronouns in the "narrow PIE" system, which gives additional support to the early split of Anatolian from the proto-language.

Petri Kallio's article "Daniel Europaeus and Indo-Uralic" is one of the two research history-oriented papers in the volume, and it deals with the oft-forgotten contributions to the Indo-Uralic hypothesis by the Finnish scholar Daniel Europaeus. Kallio shows that Europaeus was indeed the first supporter of the idea that the Indo-European and Uralic languages were related, and even though he has been largely forgotten in recent works and had a questionable reputation in Finnish linguistic circles in his own time, the other early pioneers of the Indo-Uralic field (such as Holger Pedersen) gave credit to him. 
In the other research history article in the volume, "Bojan Čop's Indo-Uralic hypothesis and its plausibility", Simona Klemenčič offers a detailed and interesting presentation of the Indo-Uralic oeuvre of the famous Slovenian Indo-Europeanist Bojan Čop. Although the article serves its purpose well in providing a good overall picture of Čop's ideas, it would have been even more useful if Čop's ideas would have been compared with more recent research results on Indo-European and Uralic, as especially many of Čop's Uralic reconstructions are outdated by now. Of course, the listing of Čop's work in this way makes it easier for other researchers to refer to his early ideas.

An especially interesting part in Klemenčičss paper is her comment on a Slovene etymological dictionary (Bezlaj 1977), which lists Uralic words such as Mordvin paygo 'mushroom' as cognates (!) to the Slovenian word spûžva 'Spongia officinalis'. This shows the extent to which the representations of the Indo-Uralic hypothesis can differ within historical linguistics.

Fredrik Kortlandt, a researcher with a well-known publication record in Indo-Uralic matters, deals with the reconstruction of IndoUralic phonology and morphology in his article "Indo-European $o$-grade presents and the Anatolian hi-conjugation", arguing, among other things, that the Indo-European vowel ${ }^{*} o$ emerged as a result of lowering of Proto-Indo-Uralic ${ }^{\star} u$. The article has relevance for ProtoIndo-European and the Indo-Anatolian hypothesis, but less so for the Uralic side. The author mentions Indo-Uralic aspects several times but does not present any actual data from Uralic languages or any Proto-Uralic reconstructions.

Guus Kroonen's article “The Proto-Indo-European mediae, Proto-Uralic nasals from a glottalic perspective" is an interesting account of the use of the Indo-European glottal theory in the reconstruction of Indo-Uralic phonology. Kroonen argues in favour of correspondences between Indo-European glottal stops (traditionally reconstructed as voiced) and Uralic nasals. However, the article is very short, and includes only rather few etymologies, most of which contain various problems, as the author himself notes. The article offers interesting prospects, but proving that these are correct would require much more evidence.

As already noted, most of the etymologies contain various problems, and the author himself states that some of the comparisons are uncertain. Regarding Uralic *äyV'burn' (in Kroonen's reconstruction, $\left.{ }^{*} \ddot{a} y-\right)$, it can be said that the 
distribution of the word is so narrow that its Proto-Uralic status is not certain. The comparison (p. 112) between PIE *ped- 'step; fall' and Uralic *pane- 'put' (that would be *pini- in Aikio's 2015 reconstruction) is semantically dubious. The Uralic word for 'gill' can only be considered as a cognate of the IE word for 'language' if the nasal ${ }^{*} y$ is reconstructed for Proto-Uralic, which seems unlikely, contra to UEW's reconstruction (the author himself admits that this is a problem). The suggested analysis of the word as a compound of *niki '??' and *ćimi 'scale' is not convincing to me, since the first part of the compound remains obscure and the semantic motivation remains unclear. In any case, the comparison of the words for 'gill' and 'language' is semantically far from secure.

Some other lexical comparisons are more promising, such as the comparison of Uralic ${ }^{\star} j a ̈ y i-$ 'ice' and PIE ${ }^{*} j e g$ - id. (the same etymology is also listed in Martin Kümmel's article in the book). However, at the present state, the idea of an IndoUralic background for PIE stops and Uralic nasals remains highly tentative and inconclusive. Very little actual Uralic data is presented in Kroonen's article (for example, one reconstruction is "based on Mari" but the Mari form itself is not provided). Including the actual forms would have made the article easier to follow.

Kroonen also mentions the possibility that the words he compares may be loanwords. These particular cases that show the relationship between Indo-European stops and Uralic nasals can hardly be considered loanwords, at least that does not seem very convincing to me such sound substitutions are not attested in any other loanword layers of Uralic, and similar problems with reconstructions and semantics concern possible loanwords as do assumed genetic cognates.

Martin Kümmel's contribution "Thoughts about Pre-Indo-European stop systems" deals with a topic that is similar to that of the previous article, but its scope is much larger and it discusses both the Indo-Uralic and Indo-Anatolian sound systems in depth, and it also presents many more etymological equations. This is arguably one of the most important studies in the volume from the point of view of Uralic linguistics, as Kümmel discusses both Indo-European and Uralic evidence for the reconstruction the Proto-Indo-Uralic and Proto-Indo-Anatolian stop systems.

Kümmel discusses a recent idea proposed by Kloekhorst (2016), who reconstructs a contrast of 
length for the Proto-Anatolian stop system, instead of the traditional system of contrast of voice. Kümmel compares these possibilities to reconstruct the Indo-Anatolian background for this system and compares the developments in Anatolian and the non-Anatolian IE languages, basing his discussion on typological data (he also discusses the substitution of voiced and voiceless stops in Germanic and Slavic loanwords into Finnic and Saami as parallel evidence, as these also show the voiced stops becoming single voiceless stops and the voiceless stops being substituted by geminate stops). Kümmel concludes that it is more likely that Kloekhorst's Anatolian stop system developed from a system of voicedvoiceless contrast, rather than assuming that PIA had the system that can be reconstructed for ProtoAnatolian and that the non-Anatolian Indo-European system would have resulted from degemination.

Kümmel also provides an interesting list of Indo-European-Uralic cognates. Kümmel is clearly aware of the problem that the discrepancy between the Proto-Indo-European and Proto-Uralic stop systems presents, as PU had only one series of voiceless stops. He admits that "[a]ll of these potential equations must be considered quite tentative at our present state of knowledge", and many of the Indo-Uralic comparisons involve a similar semantic haziness, as is noted by Kroonen; some of the comparisons are the same as those made by Kroonen. Some reconstructions are uncertain: to mention the most problematic cases, the possible Uralic word for 'woman', *niyä in UEW's reconstruction, is an infamously difficult etymology (it is not at all certain that the words grouped under this entry in the UEW are real cognates), see Helimski (2005: 34), *nin $V$ 'maggot' is considered uncertain even by UEW due to the uncertain vowel correspondences, and some other Uralic forms involve arbitrary segmentation of Uralic forms (in Kümmel's reconstruction, *im-ta- 'feed', *say-ća 'stand', ${ }^{\star}$ jey-si (bow'), even though these forms are opaque in the light of Proto-Uralic derivation rules. This means that even the more rigorously assembled lists of Indo-Uralic cognates contain many uncertain and problematic cases, and the lexical evidence in favour of IndoUralic is really far from conclusive.

The appendix to Kümmel's article contains an impressive list of possible cognates in the field of morphology, as well as a longer list of possible Indo-Uralic lexical cognates than the ones discussed in the main text. In the list of potential Indo-Uralic etymologies, those which 
are commonly considered loans are marked separately. These include cases like PU ${ }^{*}$ meta $\sim \mathrm{PIE}{ }^{*}$ medu(or $\mathrm{med}^{h} u$ in a more traditional reconstruction) 'honey', which is almost universally considered a loan. Not all of the etymologies can be discussed here in detail, but some remarks can be made: For 'horn', the traditional more traditional reconstruction of ${ }^{*}$ corwa is still given, contrary to the new reconstruction ( ${ }^{*}$ śarwi or ${ }^{*}$ ćarwi) by Aikio (2015; cf. also Zhivlov 2014). The complicated etymology of $\star^{*} u k i$ - 'drink' is also mentioned here; this is discussed in more detail by Michaël Peyrot in the same volume (see below).

It is good to note that Kloekhorst's Proto-Indo-Anatolian system of stops has also recently been discussed by Simon (2019). Kümmel does not criticise Kloekhorst's Proto-Anatolian reconstruction but according to Simon's critical observations, Kloekhorst's ideas should be rethought, as his arguments do not exclude contrast in voice, and evidence from Anatolian loanwords into neighbouring languages such as Ugaritic or NeoAssyrian support the traditional interpretation. It will be interesting to see what further research brings to this discussion about Anatolian and Indo-Anatolian stops.

Even though Kümmel gives cautious support for the Indo-Ana- tolian hypothesis, he nevertheless admits that the Indo-Anatolian and Indo-Uralic hypotheses are quite different. In his view, Indo-Anatolian and non-Anatolian IndoEuropean are quite similar, and the chronological gap between the two stages cannot have been very long, whereas Proto-Indo-Anatolian and Proto-Indo-Uralic are quite different and the difference in time between the two proto-languages must have been significant.

In the article "The Anatolian 'ergative"', Milan LopuhaäZwakenberg writes about the origin of the Anatolian suffix (Hittite sg. -anza, pl. -anteš and its cognates in other Anatolian languages) used as the case-form of neuter nouns in subject position. Lopuhaä-Zwakenberg concludes that the "Classical Indo-European" (post-Anatolian Indo-European) alignment system with ${ }^{\star}$-om as the suffix for neuter nouns in nominative is a common innovation. This gives further support for the IndoAnatolian hypothesis, although the author claims that this innovation alone is not enough to prove the early separation of Anatolian.

Alexander Lubotsky's article "The Indo-European suffix *-ensand its Indo-Uralic origin" discusses an Indo-European suffix that has received only marginal attention in the field of Indo-European 
linguistics. The possible Indo-Uralic background of the suffix *-ens is dealt with only very briefly in the end, although it would have been interesting and useful to see a more detailed discussion of its possible Uralic cognates; the simple reference to Collinder (1960) and Mikola (1988) without presenting any actual data is hardly enough for those readers who are not familiar with Uralic. It is, of course, legitimate to discuss only the Indo-European or Indo-Anatolian aspects of this problem, but the title of the article gives hope of a wider Indo-Uralic treatment.

Rosemarie Lühr's article "Headedness in Indo-Uralic" deals with questions of Indo-Uralic syntax and the concept of headedness in particular. The author must be given credit for tackling a very complicated problem. However, the article suffers from some methodological issues. The author uses Old Hungarian syntax to represent the most archaic state of affairs in Uralic syntax, but it is not at all obvious that this is the best representation of Uralic in this respect. Despite the relatively early attestation of Old Hungarian, it does not reflect the best possible example of Proto-Uralic syntax, and its value for Uralic reconstruction can in no way be compared to the value of Hittite or Vedic for the reconstruction of
Proto-Indo-European syntax. The author's ideas about Proto-IndoUralic syntax would certainly require more data from the other Uralic languages. The author concludes that "convergent head directionality structures can be used as proof of a common proto-language for Uralic and Indo-European with Hittite as the main exponent of the Indo-European branch" but notes that "more evidence is needed". Lühr's article can be seen as an interesting account of possible ProtoIndo-Uralic syntactic features, but the issue is far from settled.

Michaël Peyrot's article "IndoUralic, Indo-Anatolian, Indo-Tocharian" lists evidence for both the Indo-Uralic and Indo-Anatolian hypotheses, as well as for IndoTocharian (the latter hypothesis, widespread but not universally accepted in IE studies, is that Tocharian was the next branch to split off after Anatolian). The article is a detailed account of the evidence for Indo-Anatolian and Indo-Tocharian, and it also gives an unacquainted reader a good overview of the topic. Peyrot provides many detailed remarks on some problematic Indo-Uralic cognates, too. On pages 191-195, he discusses the problems of the Uralic verb for 'drink' ( ${ }^{*} j u k e-$ in UEW, recently reconstructed as ${ }^{\star} j i y i$ - by Zhivlov 2014: 116-117) and its possible 
Indo-European (Indo-Anatolian) cognate ${ }^{\star} h_{1} e g^{w h_{-}}$'drink' (reflected by Hittite $e k u^{z i_{-}}$'drink', Tocharian A \& B yok- 'drink' and some derivatives in other Indo-European languages). This Indo-Uralic comparison has recently been argued for by Kassian et al. (2015), and it has been criticised by Kallio (2015: 370), especially due to discrepancies on the Uralic side: Kallio has argued that the reconstruction of the word-initial ${ }^{*} j$ - in the Uralic form makes the Indo-Uralic etymology unlikely.

Peyrot is more optimistic about the etymology and argues in favour of the more traditional Uralic reconstruction with ${ }^{*} u$-vocalism. In this regard, a reference to Zhivlov (2014: 115-117) would have been in order, as he deals precisely with the reflexes of ${ }^{*} i$ in the words in question, arguing for specific WestUralic changes suggesting that the labial vowels in Finnic and Saami are later innovations, and the Hungarian and Samoyed cognates more archaic, contrary to what Peyrot claims.

In his criticism of the new reconstructions of this verb, Peyrot is, in a way, correct in noting that it is difficult to assume a "change ${ }^{{ }} i>$ ${ }^{*} u$ in Finno-Ugric" - it is indeed so that there is no such change in the Finno-Ugric branch, but this is rather because no Finno-Ugric proto-language can be securely reconstructed, at least on a phonological level. As both Hungarian $i$ - and Mari jüa- quite clearly point to ${ }^{*} i$, it is obvious that no Finno-Ugric stage for this word can be reconstructed, and that the $u$ reflexes in Western Uralic must be explained as later developments. The parallel cases showing similar vocalism in Proto-Finno-Ugric/ Proto-Uralic can also, in most cases, be explained as something other than Finno-Ugric innovations, while some other cases, such as PU *joysi *jinsi 'bow', still pose problems that have not been solved by even the best specialists in Uralic historical phonology (see Zhivlov 2014: 139; Aikio 2015: 65).

Peyrot also discusses the interrogatives with ${ }^{*} m$ - in Indo-European with their possible relations to Uralic interrogatives. The Indo-European ${ }^{*} m$ - interrogatives include forms like Hittite maši- 'how many' and Tocharian A mänt 'how', and possibly Celtic forms like Old Irish má 'if'. Peyrot notes that these might reflect a Proto-Indo-European system that has been lost in most branches, and that the Indo-European forms with ${ }^{\star} m$ - might be cognates with the well-attested Uralic interrogatives (such as Hungarian $m i$, Finnish $m i-k \ddot{a}$, etc.). To me, this looks like more promising and interesting proof of a possible relationship than the lexical cognates 
discussed by Peyrot, and it will be interesting to see whether future research will shed more light on the history of these Indo-European interrogatives.

Michiel de Vaan ("Proto-IndoEuropean ${ }^{*} s m$ and ${ }^{*} s i$ 'one"') discusses the history of the Indo-European numeral ${ }^{*}$ sem-, ${ }^{*}$ sm- 'one' and its relation to the Indo-European demonstrative pronouns. Some interesting Indo-Uralic ideas (such as the relationship of the Indo-European pronouns ${ }^{*} \mathrm{so},{ }^{\star}$ to to Uralic demonstrative pronouns like Finnish $s e, t u o$ ) are presented in the latter part of the article, but these would certainly require further study. In general, de Vaan is very supportive of the Indo-Uralic hypothesis, basing his assumptions mostly on Fredrik Kortlandt's earlier ideas.

Mikhail Zhivlov's article "IndoUralic and the origin of Indo-European ablaut" is one of the most interesting and thought-provoking papers in the book. Zhivlov builds on an old idea of Bojan Čop (1975), which, he argues, has been largely neglected in the Indo-Europeanist literature. The main argument is that the different Indo-European ablaut classes correspond to the different stem types of Proto-Uralic (with the Indo-European root nouns displaying a mobile ablaut paradigm corresponding to Uralic *-a-stems, and the Indo-European root nouns with an acrostatic paradigm corresponding to Uralic ${ }^{*} i$-stems), and that it is possible to reconstruct Proto-IndoUralic predecessors for them (these Proto-Indo-Uralic stems are largely similar to the ones that can be reconstructed for Proto-Uralic). The situation in Proto-Indo-European would then have been produced through reductive developments, whereas in Proto-Uralic the IndoUralic stem types would have been largely retained.

Zhivlov (p. 221) argues that his hypothesis requires that PIE ablaut be studied separately from the accent system. He then offers various arguments for why this is so, mainly that there is no synchronic correspondence between accent and ablaut and it cannot be reconstructed for Proto-Indo-European, and that such a correspondence can only be assumed to have occurred at some Pre-PIE stage.

Zhivlov also presents a reconstruction of the Proto-IndoUralic case system (pp. 221-223). For Proto-Uralic ablative (p. 221), Zhivlov reconstructs " $t \mathrm{tA}$ instead of Janhunen's ‘ti”. Zhivlov's arguments (Samoyed ${ }^{\star}$ z can reflect PU ${ }^{*} a$ in non-initial syllables) for this are promising, and this has relevance for Uralic studies in general. Regarding the Indo-European and Uralic accusative ${ }^{*}-m$, which is often taken as evidence of the Indo-Uralic 
genetic relationship, it is interesting to note that a non-accusative background for Indo-European ${ }^{*}-m$ has recently been suggested: Pooth et al. (2019: 258) argue that Proto-IndoEuropean (= Proto-Indo-Anatolian) * $m$ was originally an allative marker of non-neuter nouns, and that the accusative function developed later. If we assume that the Indo-European and Uralic *-m-accusative markers are inherited from ProtoIndo-Uralic, we should then explain what the function of the ending was in Proto-Indo-Uralic, because, if we follow Pooth et al., it would not have been accusative, whereas Proto-Uralic * $m$ is universally considered to be the accusative ending. This casts doubt on the relationship of the Uralic and Indo-European *- $m$-accusatives, and it will be interesting to see what further research will say on this matter.

Dual ${ }^{*} k$ and Indo-European ${ }^{\star} h_{1}$ have often been considered cognates, but Zhivlov notes that since the origin of ${ }^{*}(V) n$ in the Samoyed and Ob-Ugric dual suffixes is uncertain, this question will not be discussed. I agree that this is a good approach - as noted earlier, if there is some phonological problem in the reconstruction of a grammatical marker in one of the languages being compared, it is futile to compare it with data from other language families.
Zhivlov also argues (p. 224) that the Proto-Indo-European vocalism can be explained through the following changes: any ProtoIndo-Uralic short vowel $>\mathrm{PIE}{ }^{*} e$, any long vowel $>\mathrm{PIE}{ }^{\star} o$. While this may of course be correct, the chances of finding an Indo-Uralic cognate with these rules are quite high, with the Proto-Uralic system of eight vowels (which likewise do not include any long vowels). This is in disagreement with the ideas that Kortlandt suggests in the same volume about the origin of PIE ${ }^{\star} O$, which is a good example of two scholars of Indo-Uralic working with different rules of historical phonology. Similar remarks can be made about Zhivlov's idea of a pre-Indo-European change ${ }^{*} t>$ ${ }^{*} s$ in word-final position. The idea that ${ }^{*} t>{ }^{*} s$ happened precisely in word-final position contradicts the more widespread idea that the change was ${ }^{\star} t i>{ }^{*} s i$, and that it also occurred in other environments, not only word-finally (for example, see de Vaan's article in the volume, p. 213 , where the change ${ }^{\star} t i>{ }^{*} s i$ is essential for the explanation of the phonological developments that have produced the Indo-European system of demonstrative pronouns with ${ }^{*} s$ - and ${ }^{\star} t$-).

Zhivlov's ideas also include points that are relevant not only for Indo-Uralic but also for Indo-Ana- 
tolian. For example, on pp. 231-232, Zhivlov offers an interesting account of ablaut in the kinship terms with *-ter, arguing for root ablaut levelling in PIE after the separation of Anatolian.

In general, Zhivlov's account of the Indo-Uralic background of Indo-European ablaut is promising, but more lexical cognates could have been presented to support his ideas, and in the present form, the article is a bit hard to follow. As noted by author, the reconstruction of paradigms and not just individual morphemes or lexemes is definitely a good sign. But this kind of hypothesis should be backed up with sound correspondences; a comparison of stem types is simply not enough. It is difficult to understand how certain Uralic and IndoEuropean stem types correspond to one another if no lexical cognates are presented. Zhivlov argues that this is because not very many convincing Indo-Uralic cognates can be found, but Zhivlov's (2017) study on another Indo-Uralic topic provides more tentative lexical material; let us hope he returns to this topic in the future.

I must also remark that one can only arrive at these conclusions about the history of ablaut by simply assuming that the Proto-IndoEuropean phonological system can be derived from a system that was very similar to that of Proto-Uralic; however, there is no immediate need to do so, and it is not at all certain that Proto-Uralic would have retained the Proto-Indo-Uralic system of stem types so well. Theoretically, a number of different preceding systems could be proposed for Indo-European, and if enough reductive developments are assumed, it becomes very difficult to prove that the hypothetical pre-Indo-European reconstructions are correct.

\section{Concluding remarks}

To conclude, this volume contains many interesting studies, which are in general of high quality, and it can be recommended to any IndoEuropeanist or Uralicist who is interested in long-range comparison and the early relations of the two families. It is good that the material here is not mixed up with more distant Nostratic comparisons. The critical remarks presented above do not lessen the value of the book, but I hope they show that the IndoUralic hypothesis is still too shakily grounded to be accepted, and at least I remain unconvinced by it.

Regarding the Indo-Uralic hypothesis in general, a Caucasian superstrate is often mentioned (see Introduction, p. 10; Bjørn, p. 40; and Kortlandt, p. 102) as the reason PIE and PU are typologically so 
divergent and as an explanation for why the PIE vowel system (reconstructed as a one-vowel-system by some) has become so radically simple. However, it seems that the idea of a Caucasian substrate is obscure and not well established and is used as a kind of deus ex machina. Even some supporters of the hypothesis (Matasović 2012: 306-307) admit that part of the evidence for a Caucasian superstrate depends on the viewpoints of PIE reconstruction, and in any case the idea of a superstrate is hindered by the lack or at least very small number of Caucasian loanwords (Matasović ibid.).

One general thing that should be noted is that in many articles, the Uralic data is neglected or receives too little attention, or it is dealt with in a misleading manner. More actual Uralic data from the attested languages would have enriched several of the articles, as in many cases only reconstructions are given. For future conferences and publications about the relationship of Indo-European and Uralic, more contributions from Uralicists would be desirable. Most of the contributions dealing with Indo-Uralic also approach the topic from an Indo-European point of view, and various problems and developments on the Indo-European side are explained through IndoUralic comparisons, but similar approaches to Uralic are not made. It is also troubling that very little data from the attested Uralic languages is presented in the articles, which mostly employ evidence from reconstructions, which is always tricky.

\section{Sampsa Holopainen}

\section{References}

Adiego, Ignasi-Xavier. 2016. Anatolian languages and Proto-IndoEuropean. Veleia 33. 49-64.

Aikio, Ante (Luobbal Sámmol SámMOL ÁNTE). 2014. The Uralic-Yukaghiric lexical correspondences: Genetic inheritance, contact of chance resemblance? Finnisch-Ugrische Forschungen 62. 7-76.

Aikio, Ante (Luobbal Sámmol SámMOL ÁnTe). 2015. The Finnic 'secondary $e$-stems' and Proto-Uralic vocalism. Journal de la Société Finno-Ougrienne 95. 26-66.

Beekes, Robert Stephen Paul. 2011. Comparative Indo-European linguistics. Second edition. Revised and corrected by Michiel de Vaan. Amsterdam \& Philadelphia: John Benjamins.

Bezlaj, France. 1977-2007. Etimološki slovar slovenskega jezika I-V. Ljubljana: SAZU ZRC.

Collinder, BJÖRN. 1960. Comparative grammar of the Uralic languages. Stockholm: Almqvist \& Wiksell.

Čop, BoJAN. 1975. Die indogermanische Deklination im Lichte der indouralischen vergleichenden Grammatik. Ljubljana: SAZU. 
Helimski, Eugene. 2005. The 13th Proto-Samoyedic vowel. In Wagner-Nagy, Beáta (ed.), Mikola-konferencia 2004, 27-40. Szeged: SzTE.

Holopainen, SAmpsa. 2019. Indo-Iranian borrowings in Uralic: Critical overview of the sound substitutions and distribution criterion. Helsinki: University of Helsinki. http://hdl.handle.net/10138/307582 (Doctoral dissertation.)

Honti, LÁszló. 2012. Das Zeitalter und die Entstehung der Personalpronomina mit velaren Vokalen. In Hyytiäinen, Tiina \& Jalava, Lotta \& Saarikivi, Janne \& Sandman, Erika (eds.), Per Urales ad Orientem: Iter polyphonicum multilingue. Festskrift tillägnad Juha Janhunen på hans sextioårsdag den 12 februari 2012 (Mémoires de la Société Finno-Ougrienne 264), 121-129. Helsinki: Finno-Ugrian Society.

Hyllested, Adam. 2009. Internal reconstruction vs. external comparison: The case of the Indo-Uralic laryngeals. In Olander, Thomas \& Rasmussen, Jens Elmegård (eds.), Internal reconstruction in IndoEuropean: Methods, results, and problems (Copenhagen studies in Indo-European 3), 3-28. Copenhagen: Museum Tusculanum Press.

JANHUNEN, JuhA. 1981. Uralilaisen kantakielen sanastosta. Journal de la Société Finno-Ougrienne 77. 219-274.

JaNHUNEN, Juha. 1982. On the structure of Proto-Uralic. Finnisch-Ugrische Forschungen 44. 23-42.

Kallio, Petri. 2004. Tocharian loanwords in Samoyed? In Hyvärinen, Irma \& Kallio, Petri \& Korhonen, Jarmo (eds.), Etymologie, Entlehnungen und Entwicklungen:
Festschrift fur Jorma Koivulehto zum 7o. Geburtstag (Mémoires de la Société Neophilologique de Helsinki 63), 129-137. Helsinki: Société Neophilologique.

Kallio, Petri. 2015. Nugae Indo-Uralicae. Journal of Indo-European Studies 43. 368-375.

Kassian, Aleksei \& Zhivlov, Mikhail \& Starostin, George. 2015. Proto-Indo-European-Uralic comparison from the probabilistic point of view. Journal of Indo-European Studies 43. 301-347.

KESKJ = Лыткин, В. И. \& Гуляев, Е. С. 1999. Краткий этимологический словарь коми языка. Сыктывкар: Коми книжное издательство.

Kloekhorst, Alwin. 2008a. Etymological dictionary of the Hittite inherited lexicon (Leiden Etymological Dictionary Series, Vol 5). Leiden \& Boston: Brill.

Kloekhorst, Alwin. 2008b. Some Indo-Uralic aspects of Hittite. Journal of Indo-European studies 36. 88-95.

Kloekhorst, Alwin. 2016. The Anatolian stop system and the IndoHittite hypothesis. Indogermanische Forschungen 121. 213-247.

Kloekhorst, Alwin. 2018. Anatolian evidence suggests that the IndoEuropean laryngeals ${ }^{\star} h_{2}$ and ${ }^{\star} h_{3}$ were uvular stops. Indo-European linguistics 6. 69-94.

KüMmel, Martin. 2007. Konsonantenwandel: Bausteine zu einer Typologie des Lautwandels und ihre Konsequenzen für die vergleichende Rekonstruktion. Wiesbaden: Reichelt.

Matasović, Ranko. 2012. Areal typology of PIE: the case for Caucasian connections. Transactions of the Philological Society 110. 283-310. 
Fresh views on the early history of Indo-European and its relation to Uralic

Mikola, Tibor. 1988. Geschichte der samojedischen Sprachen. In Sinor, Denis (ed.), The Uralic languages: Description, history and foreign influences (Handbuch der Orientalistik 8: Handbook of Uralic studies 1), 219-263. Leiden: E. J. Brill.

MSzFE = LAKó, GYörgY. 1971-1978. A magyar szókészlet finnugor elemei. Budapest: Akadémiai Kiadó.

Olander, Thomas. 2019. Indo-European cladistic nomenclature. Indogermanische Forschungen 124. 231-244.

Pooth, Roland \& Kerkhof, Peter Alexander \& Kulikov, LeOnid \& BARĐDAL, JóHANNA. 2019. The origin of non-canonical case marking of subjects in Proto-Indo-European. Indogermanische Forschungen 124. 245-263.

RAsmussen, JENS ElmegÅRD. 2005. Der Akkusativ auf ${ }^{*}-m$ im Indogermanischen und Uralischen: Kontakt oder Erbe? In Meiser, Gerhadt \& Hackstein, Olav (eds.), Sprachkontakt und Sprachwandel: Akten der XI. Fachtagung der Indogermanischen Gesellschaft, 17.-23. September 2000, Halle an der Saale, 525-535. Wiesbaden: Reichert.

Rieken, Elisabeth. 2009. Der Archaismus des Hethitischen: Eine Bestandsaufnahme. Incontri Linguistici 32. 37-52.

SÁrosi, Zsófia. 2003. Az ősmagyar kor: morfématörténet. In Kiss, Jenő \& Pusztai, Ferenc (eds.), Magyar nyelvtörténet, 129-173. Budapest: Osiris Kiadó.

Serangeli, Matilde. 2019. Introduction. In Serangeli, Matilde \& Olander, Thomas (eds.), Dispersals and diversification: Linguistic and archaeological considerations on the early stages of Indo-European, 1-20. Leiden \& Boston: Brill.

Simon, Zsolt. 2019. The Anatolian stop system and the Indo-Anatolian hypothesis - revisited. In Serangeli, Matilde \& Olander, Thomas (eds.), Dispersals and diversification: Linguistic and archaeological considerations on the early stages of Indo-European, 236-250. Leiden \& Boston: Brill.

UEW = REDEI, KÁROLY. 1988. Uralisches Etymologisches Wörterbuch. Band I-II: Unter Mitarbeit von Marianne Bakró-Nagy, Sándor Csúcs, István Erdélyi †, László Honti, Éva Korenchy †, Éva K. Sal und Edit Vértes, Band III: Register Zusammengestellt von Attila Dobó und Éva Fancsaly. Wiesbaden: Harrassowitz.

Zhivlov, Mikhail. 2014. Studies in Uralic vocalism III. Journal of Language Relationship / Bonpocbl яblзыкого родства 12. 113-148.

Zhivlov, Mikhail. 2017. Отражение ностратических огубленных гласных в индоевропейском. In Саенко, М. Н. (ed.), Памяти B. М. Иллич-Свитыча: Материаль круглого стола. Москва: Институт славяноведения РАН.

Zhivlov, Mikhail. 2018. Прасамодийский ${ }^{*}$ s - фонология и фонетика. (Presentation at $\mathrm{Ce}$ минар по сравнительно-исторической фонетике самодийских языков, Институт языкознания РАH, 25.-26.3.2018.) https://www.academia.edu/ 38048065/Прасамодийский_s_ фонология_и_фонетика 